\title{
Development features of volcanic rocks of the Yingcheng Formation and their relationship with fault structure in the Xujiaweizi Fault Depression, Songliao Basin, China
}

\author{
Cai Zhourong ${ }^{1,2,3}$, Huang Qiangtai ${ }^{4}$, Xia Bin ${ }^{1,2,3 *}$, Lü Baofeng1, 2, 3, Liu \\ Weiliang ${ }^{1,2,3}$ and Wan Zhifeng ${ }^{1,2,3}$ \\ ${ }^{1}$ School of Marine Sciences, Sun Yat-sen University, Guangzhou, Guangdong 510006, China \\ ${ }^{2}$ Guangdong University Key Laboratory of Offshore Oil Exploration and Development, Guangzhou, Guangdong 510006, \\ China \\ ${ }^{3}$ Guangdong Provincial Key Laboratory of Marine Resources and Coastal Engineering, Guangzhou, Guangdong 510006, \\ China \\ ${ }^{4}$ Guangzhou Institute of Geochemistry, CAS, Guangzhou, Guangdong 510640, China
}

(C) China University of Petroleum (Beijing) and Springer-Verlag Berlin Heidelberg 2012

\begin{abstract}
The Xujiaweizi Fault Depression is located in the northern Songliao Basin, Northeast China. The exploration results show that the most favorable natural gas reservoirs are in the volcanic rocks of the Yingcheng Formation $\left(\mathrm{K}_{1} \mathrm{yc}\right)$. Based on seismic interpretation, drill cores and the results of previous research, we analyzed the distribution of faults and the thickness of volcanic rocks in different periods of $\mathrm{K}_{1} \mathrm{yc}$, and studied the relationship of volcanic activities and main faults. Volcanic rocks were formed in the Yingcheng period when the magma erupted along pre-existing fault zones. The volcanic activities strongly eroded the faults during the eruption process, which resulted in the structural traces in the seismic section being diffuse and unclear. The tectonic activities weakened in the study area in the depression stage. The analysis of seismic interpretation, thin section microscopy and drill cores revealed that a large number of fractures generated in the volcanic rocks were affected by later continued weak tectonic activities, which greatly improved the physical properties of volcanic reservoirs, and made the volcanic rocks of $\mathrm{K}_{1} \mathrm{yc}$ be favorable natural gas reservoirs. The above conclusions provide the basis to better understand the relationship of the volcanic rock distribution and faults, the mechanism of volcanic eruption and the formation of natural gas reservoirs in volcanic rocks.
\end{abstract}

Key words: Volcanic rock, development features, Yingcheng Formation, Xujiaweizi Fault Depression, Songliao Basin

\section{Introduction}

The Xujiaweizi Fault Depression is located in the northern Songliao Basin, Northeast China, where the largest oil and gas reservoirs in the Songliao Basin have been found, such as the Daqing Oilfield. It is the most highly explored part of the basin. The reservoirs are characterized by oil in shallow strata and gas in deep strata. Since the shallow exploration entered the stage of high water-cut production, and the well Xushen 1 obtained a high-yield natural gas flow from Cretaceous volcanic rocks in 2002, exploration has discovered substantial reserves of deep-layer gas (Zou et al, 2010). The western depression is separated by faults

*Corresponding author. email: xiabin01@gmail.com

Received November 3, 2011 from the Ancient Central Uplift, and the transitional slope areas in the southeast and northeast of the depression are separated from the Zhao 59-Wanlong ancient uplift and the northeast uplift area, respectively (Fig. 1). The depression extends approximately north-south, with a maximum width of $40 \mathrm{~km}$ in E-W direction and an N-S length of about 80 $\mathrm{km}$. The structure pattern is characterized by rifting in the west and overlap in the east, block-faulting in N-S direction. The deep strata of the depression include the Upper Jurassic Huoshiling $\left(\mathrm{J}_{3} \mathrm{hs}\right)$, the Lower Cretaceous Shahezi $\left(\mathrm{K}_{1} \mathrm{sh}\right)$, Yingcheng $\left(\mathrm{K}_{1} \mathrm{yc}\right)$, Denglouku $\left(\mathrm{K}_{1} \mathrm{~d}\right)$ and Quantou Formations $\left(\mathrm{K}_{1} \mathrm{q}\right)$ from bottom to top. The Huoshiling period was the initial rifting stage, dominated by volcanism. The Shahezi period was the strong rifting stage and the strata were mainly lake sediments. The Yingcheng period was the fault-sag transition stage, the first and third members were dominated 
by volcanism, the second member was absent and the fourth member of Yingcheng Formation $\left(\mathrm{K}_{1} \mathrm{yc}^{4}\right)$ was river-delta and shallow lake facies. The Denglouku period and the latest period were the depression stage, and river delta and lake facies sediments were developed (Chen et al, 1999; Chi et al, 2002; Yin et al, 2002). The Xuxi Fault (including north and south sections), Xuzhong Fault and Xudong Fault belts were developed in the fault depression, and controlled the formation and evolution of deposition and structure (Meng et al, 2006; Zhang et al, 2010) (Fig. 1). Large natural gas reservoirs have been discovered in deep strata in volcanic rocks of $\mathrm{K}_{1} \mathrm{yc}^{1}$ and $\mathrm{K}_{1} \mathrm{yc}^{3}$. In recent years, on the basis of high-resolution $3 \mathrm{D}$ seismic and rock geochemistry data from drilling, more information has been obtained about the lithology, composition and distribution of volcanic rocks of $\mathrm{K}_{1} \mathrm{yc}$ (Ren et al, 2004; Hou et al, 2004; Feng, 2006; Huang et al, 2006). However, research into the mechanisms of volcanic eruption is incomplete, and the study of key fundamental problems in the relationships between the complex fault structure and volcanic development is inadequate, which restricts the understanding of the volcanic gas reservoirs and the level of gas exploration in a certain extent. Based on 3D seismic exploration and drill core data, we analyze the relationship between the volcanic development characteristics and fault structure, and try to reveal the evolution and genetic mechanism of the volcanic rocks of $\mathrm{K}_{1} \mathrm{yc}$.

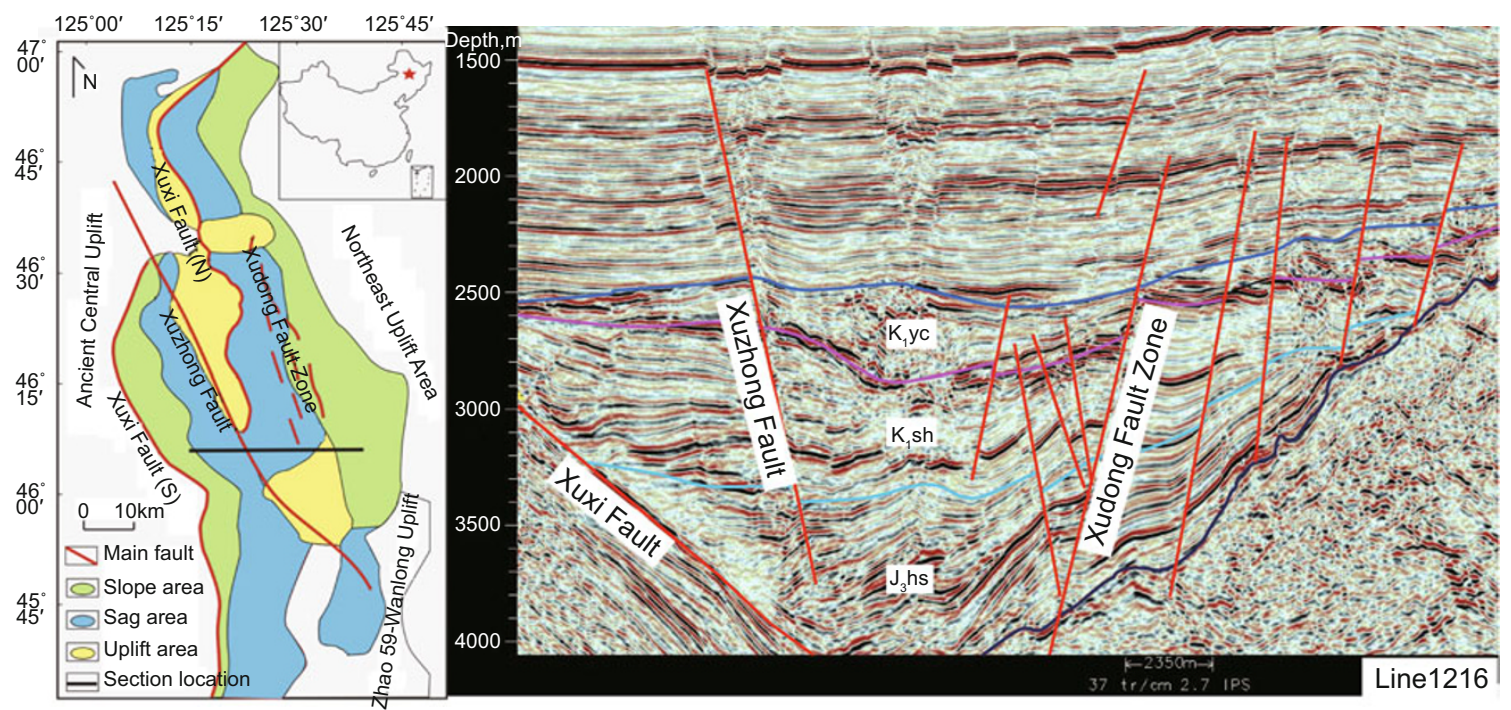

Fig. 1 The structure diagram and seismic profile of the Xujiaweizi Fault Depression

\section{Development characteristics of volcanic rocks in $\mathrm{K}_{1} \mathrm{yc}$}

The volcanic rocks of $\mathrm{K}_{1} \mathrm{yc}$ mainly developed in the first and the third members (Jin et al, 2005; Tang et al, 2008; Zhao et al, 2007). The volcanic rocks of $\mathrm{K}_{1} \mathrm{yc}^{1}$ and $\mathrm{K}_{1} \mathrm{yc}^{3}$ directly contact due to the absence of $\mathrm{K}_{1} \mathrm{yc}^{2}$. The development characteristics of the two members of volcanic rocks in $\mathrm{K}_{1} \mathrm{yc}$ will be analyzed based on the seismic data, drilling data and the results of previous studies.

\subsection{Difference of volcanic rocks between $K_{1} y^{1}$ and $\mathrm{K}_{1} \mathbf{y c}^{3}$}

The volcanic rocks of $\mathrm{K}_{1} \mathrm{yc}^{1}$ are mainly distributed in the central and southern fault depression, and most are intermediate-acid. The base of the volcanic rocks has a small amount of basic extrusives. However, the volcanic rocks of $\mathrm{K}_{1} \mathrm{yc}^{3}$ are mainly distributed in the central and northern fault depression, and are dominated by acid rocks accompanied with basic and intermediate rocks. The difference of spatial distribution between the two members of volcanic rocks is mainly affected by regional tectonic evolution (Cai et al, 2010), and the difference of lithology may be caused by different mixing degrees of crust material when the magma rose. Previous studies based on lithology and geochemical characteristics of the volcanic rocks show that the volcanic rocks in Xujiaweizi and the adjacent areas have a dual tectonic setting of continental rift and marginal arc (Wang et al, 2009; Liu et al, 1994).

\subsection{Generalities of volcanic rocks in $K_{1} y^{1}$ and $K_{1} y^{3}$}

Pyroclastic facies, extrusive facies and a mixture of the two facies are the main volcanic facies of the first member and third member in $\mathrm{K}_{1} \mathrm{yc}$, accompanied with a small amount of intrusive facies, channel facies and volcanic sedimentary facies. The pyroclastic facies in the seismic profiles are characterized by mound-like clutter, high amplitude and weak reflection (Fig. 2), mainly belonging to pyroclastic rocks, including agglomerate, breccia, and tuff. The extrusive facies are characterized by intermittent and similarly parallel strong amplitude and strong reflection, and the rock type is mainly lava, including rhyolite, dacite, andesite, and basalt (Chen et al, 2000; Liu et al, 2003). Studies on the two members of $\mathrm{K}_{1} \mathrm{yc}$ show that the multi-phase pyroclastic facies and extrusive facies overlay each other in the vertical profile. The thickness and facies characteristics of volcanic rocks are influenced obviously by the distribution of craters. The volcanic rocks are mainly pyroclastic facies with large thickness when 
close to the crater, and they are mainly extrusive facies with small thickness when far away from the crater. The volcanic activities were characterized by eruption in high areas and filling in low-lying areas (Fig. 2). In addition, the distribution of volcanic rocks shows the characteristics of center thick and surrounding thin due to weathering and erosion. Some researchers (Jiang et al, 2010; He et al, 2008) relied on drill core and seismic data to study the lithology of volcanic rocks of $\mathrm{K}_{1} \mathrm{yc}$ in the Xujiaweizi Fault Depression, and proposed that there were multiple stages of volcanic eruption in the Yingcheng period, and the eruption types included fissure, central-vent and composite types, which resulted in the volcanic rocks overlying each other in space, as well as lithology and facies changing rapidly.

It can be seen that the characteristics of volcanic facies, rock type and eruption type of $\mathrm{K}_{1} \mathrm{yc}^{1}$ and $\mathrm{K}_{1} \mathrm{yc}^{3}$ are similar, but there exist differences in the spatial distribution and lithology. The similarity of the two members of volcanic rocks makes it difficult to accurately distinguish them on the seismic profile in the middle depression. Previous studies suggested that the two members of volcanics of $\mathrm{K}_{1} \mathrm{yc}$ are formed by the same original magma chamber, and both have multi-stage and intermittent volcanic eruptions (Wang et al, 2009; 2007; Tang et al, 2001). The above development features of volcanic rocks of $\mathrm{K}_{1} \mathrm{yc}$ show that there is a close relationship between the volcanic rocks and fault structure.
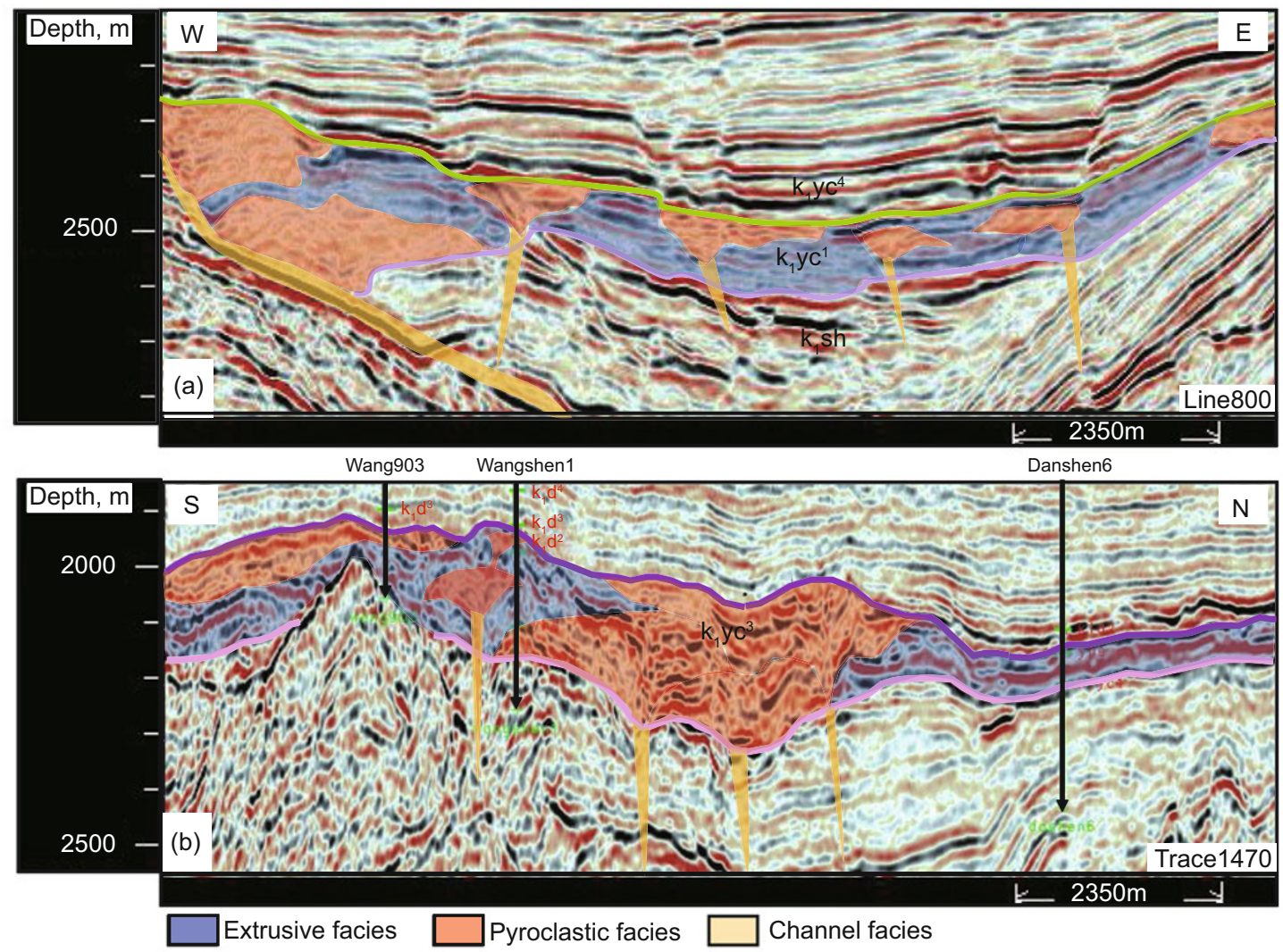

Fig. 2 The lithofacies seismic interpretation sections of volcanic rocks of $\mathrm{K}_{1} \mathrm{yc}^{1}$ (a) and $\mathrm{K}_{1} \mathrm{yc}^{3}$ (b) (the section location is shown in Fig. 3)

\section{Relationship between volcanic rocks of $K_{1} y c$ and fault structure}

\subsection{Control of main faults on the volcanic eruption and distribution}

The superimposed figures (Fig. 3) of the relationship between faults and the volcanic rocks of $\mathrm{K}_{1} \mathrm{yc}^{1}$ and $\mathrm{K}_{1} \mathrm{yc}^{3}$ were drawn from drilling data (Table 1), the structure maps and thickness maps of 3D seismic interpretation data. These reveal the characteristics of distribution and development of volcanic rocks of $\mathrm{K}_{1} \mathrm{yc}$ and the mechanism restricted by the main faults of the Xujiaweizi Fault Depression.

The volcanic rocks of $\mathrm{K}_{1} \mathrm{yc}^{1}$ are mainly distributed in the central and southern depression, and the west boundary is the southern section of the Xuxi Fault. The thickness is largest in the central depression, and the volcanic rocks gradually thin out to the east at the Xudong Slope. The thickness distribution shows that the distribution and eruption of the volcanic rocks of $\mathrm{K}_{1} \mathrm{yc}^{1}$ are closely related to the activity of the Xuzhong Fault. The thickness contour of the volcanic rocks is consistent with the strike of the Xuzhong Fault. The volcanic rocks are thick near the Xuzhong Fault, and thin when far away from the fault, which reveals that the volcanic activity along the Xuzhong Fault is characterized by fissure type and partial central-vent type eruption. The volcanic rocks are absent in the Ancient Central Uplift which is located at the rising footwall of the Xuxi Fault, but are still found in the small sag of the western Ancient Central Uplift. Therefore, the Xuxi Fault has played an important role in 
controlling the distribution of volcanic rocks of $\mathrm{K}_{1} \mathrm{yc}^{1}$. In the north-south direction, volcanic rocks of $\mathrm{K}_{1} \mathrm{yc}^{1}$ thin from south to north and they are not developed in the uplift area of west Xuxi Fault (N) and further north (Fig. 3). The Xuzhong Fault zone is the eruption center of the volcanics. From an analysis of the relationship between strata and the faults in seismic

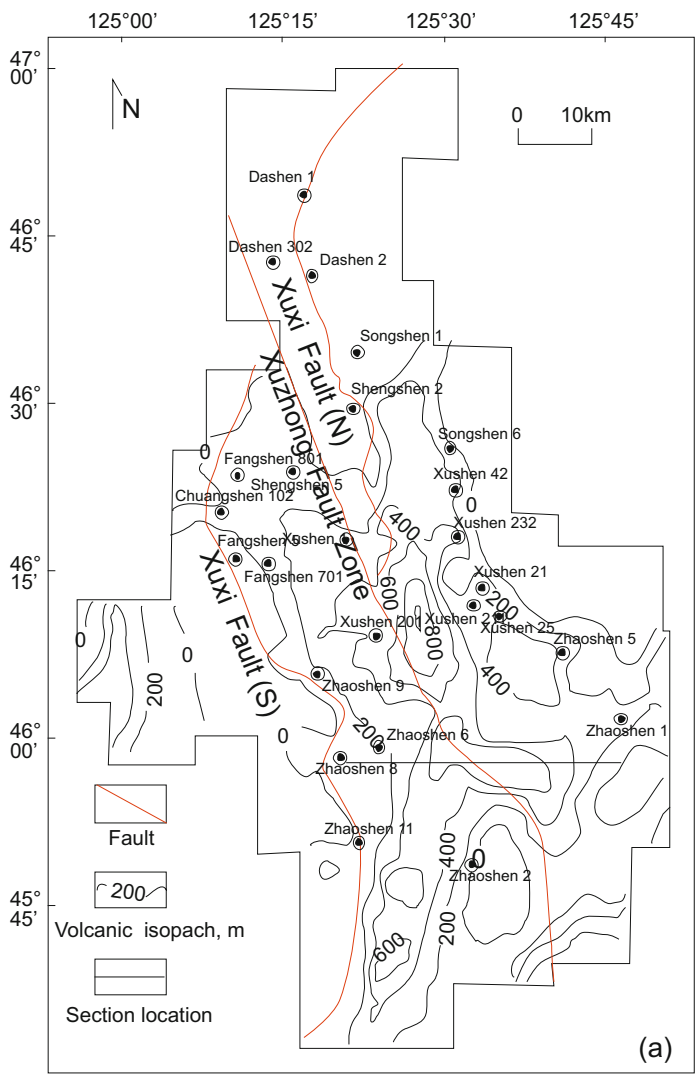

interpretation profiles, we deduce that the large-scale strikeslip activity of the Xuzhong Fault occurred from the Late Shahezi to the Yingcheng period, which was the fault-sag transition stage. The faults were strongly active and extended to the basement, which could have provided favorable channels for volcanic eruption.

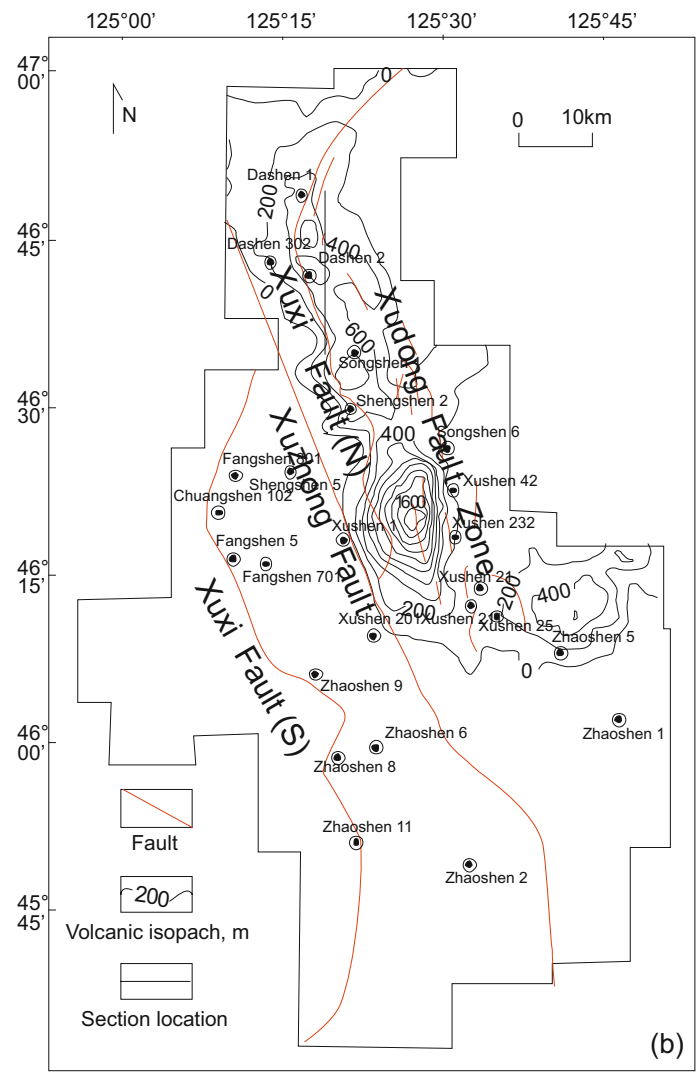

Fig. 3 The relationship between distribution of volcanic rocks of $K_{1} y^{1}$ (a) and $K_{1} y c^{3}$ (b) and faults in Xujiaweizi Fault Depression

The volcanic rocks of $\mathrm{K}_{1} \mathrm{yc}^{3}$ are distributed in the central and northern fault depression, and are superimposed on the top of the volcanic rocks of $\mathrm{K}_{1} \mathrm{yc}^{1}$. The maximum thickness of volcanic rocks is located along the Xudong Fault zone, which shows that the volcanic rocks of $\mathrm{K}_{1} \mathrm{yc}^{3}$ erupted along the fault with fissure type and partially central-vent type. The north section of the Xuxi Fault is the western boundary of the third member volcanic rocks which did not develop in the west of the fault. The southern boundary is located along the straight line from well Xushen 301 to well Xushen 27. The volcanic rocks of $\mathrm{K}_{1} \mathrm{yc}^{3}$ are thick in the middle and thin in the east and west wings, as well as thick in the south and thin in the north. The thickness is distributed along the fault zone. The above analysis shows that the distribution and eruption of volcanic rocks of $\mathrm{K}_{1} \mathrm{yc}^{3}$ are controlled by the main fault (Fig. 3). There is a close relationship between the development of the Xudong Fault zone and the eruption and distribution of volcanic rocks. The Xudong Fault zone consists of a series of small faults with nearly N-S strike. The main fault in the lower layers was formed in the strong rifting stage (Shahezi period), and the upper small faults with flower structure mainly developed during the period of $\mathrm{K}_{1} \mathrm{yc}^{3}$. The Xudong
Fault shows zonal distribution in the eastern depression. The deep main fault laid the foundation for the volcanic eruption of $\mathrm{K}_{1} \mathrm{yc}^{3}$, and the upper flower structure provided the channels for the lateral migration of magma.

The above analysis indicates that the volcanic rocks of $\mathrm{K}_{1} \mathrm{yc}^{1}$ erupted from the center to the south of the depression in the early Yingcheng period, and the eruption and distribution were mainly controlled by the Xuzhong Fault. The Xuxi Fault defines the west boundary of the volcanic rocks. The volcanic rocks of $\mathrm{K}_{1} \mathrm{yc}^{3}$ erupted from the center to the north of the depression in the late Yingcheng period, and the eruption and distribution were mainly controlled by the Xudong Fault zone (Jiang et al, 2010; Cai et al, 2010). The main faults formed in the rifting stage (from the Huoshiling to Shahezi periods) became the major channels and eruption center of rising magma, and they also controlled the distribution range of the two volcanic rock members. In the three main faults, the characteristics of fault cutting strata in the seismic section and previous studies reveal that the Xuzhong Fault was formed at the end of the Shahezi period, and was a strike-slip fault with normal and reverse faults alternating. The fault activities occurred strongly in the Yingcheng period and weakened in 
Table 1 Drilling data of volcanic rock thickness in the Xujiaweizi Fault Depression

\begin{tabular}{|c|c|c|c|c|}
\hline \multirow{2}{*}{ No. } & \multirow{2}{*}{ Well } & \multirow{2}{*}{$\begin{array}{l}\text { Well depth } \\
\text { m }\end{array}$} & \multicolumn{2}{|c|}{ Thickness, $\mathrm{m}$} \\
\hline & & & $\mathrm{K}_{1} \mathrm{yc}^{1}$ & $\mathrm{~K}_{1} \mathrm{yc}^{3}$ \\
\hline 1 & Chuang102 & 3466 & 0 & 0 \\
\hline 2 & Zhaoshen1 & 3050 & 306.5 & 0 \\
\hline 3 & Zhaoshen 2 & 3175.2 & 117 & 0 \\
\hline 4 & Zhaoshen 5 & 3970 & 367 & 194 \\
\hline 5 & Dashen 1 & 4650 & 0 & 452 \\
\hline 6 & Dashen 2 & 4650 & 0 & 452 \\
\hline 7 & Dashen 302 & 3600 & 0 & 198 \\
\hline 8 & Fangshen5 & 3340 & 34 & 0 \\
\hline 9 & Fangshen 701 & 3935 & 124 & 0 \\
\hline 10 & Fangshen 801 & 3910 & 22 & 0 \\
\hline 11 & Shengshen2 & 3816 & 0 & 772 \\
\hline 12 & Shengshen 5 & 4175 & 47.5 & 0 \\
\hline 13 & Songshen 1 & 3935 & 0 & 565 \\
\hline 14 & Songshen 6 & 3850 & 0 & 256 \\
\hline 15 & Xushen 1 & 4548 & 258 & 0 \\
\hline 16 & Xushen 201 & 4333 & 305 & 0 \\
\hline 17 & Xushen 232 & 4238 & 423 & 211 \\
\hline 18 & Xushen 25 & 4483 & 244 & 190 \\
\hline 19 & Xushen 42 & 4546 & 443 & 0 \\
\hline 20 & Xushen 21 & 4273 & 409 & 167 \\
\hline 21 & Xushen 211 & 4291 & 180 & 104 \\
\hline 22 & Zhaoshen 11 & 3415 & 37 & 0 \\
\hline 23 & Zhaoshen 6 & 4117 & 190 & 0 \\
\hline 24 & Zhaoshen 8 & 3450 & 209 & 0 \\
\hline 25 & Zhaoshen 9 & 3982.3 & 223 & 0 \\
\hline
\end{tabular}

the depression period. The Xudong Fault zone was formed in the period of $\mathrm{K}_{1} \mathrm{yc}^{3}$, and was a flower structure zone composed of a main fault dipping southwest and several branch faults. It provided channels for the eruption of volcanic rocks of $\mathrm{K}_{1} \mathrm{yc}^{3}$. The Xuxi Fault played a key role in the process of the eruption of the volcanic rocks. It was formed in the initial stage of the rifting period or earlier, extended directly to the deep crust, and was a key detachment fault which controlled the formation and evolution of the Xujiaweizi Fault Depression. The measurement of the fault displacement shows that the strong activity of the Xuxi Fault took place in the strong rifting stage (i.e. Shahezi period) when the fault displacement increased to more than $14 \mathrm{~km}$, and during the Yingcheng period it was only $4 \mathrm{~km}$. Therefore, the Xuxi Fault played a leading role in the dynamic mechanism of volcanic eruption in the Yingcheng period. It reached the deep magma chamber by connecting with the crustal detachment faults. The Xuzhong Fault and Xudong Fault were the branch faults which developed later than the Xuxi Fault, and became the two main channels after the magma reached the basement of the fault depression. The upwelling and eruption of a large amount of magma decreased the speed of fault extension, and speeded up the conversion of the structure from rifting to depression in the Xujiaweizi area (Fig. 4).

\subsection{Transformation of volcanic activity on pre- existing faults}

The tensional fractures formed during the strong rifting period provided channels for the volcanic eruptions of $\mathrm{K}_{1} \mathrm{yc}$. The volcano had an important transformation effect on the faults when it rose along the faults due to the erosion by the heated magma. Some fault zones turned into the areas where channel facies of volcanic rocks developed, which showed different reflection characteristics compared with strata on both sides of the fault. A large area of volcanic activity could make the pre-existing faults blur beyond our recognition or even disappear in the seismic profile. For example, the Xuzhong Fault was one of the deep faults within the depression with NW-SE strike and high dip angle, and the fault extended down to the basement and also spreaded out

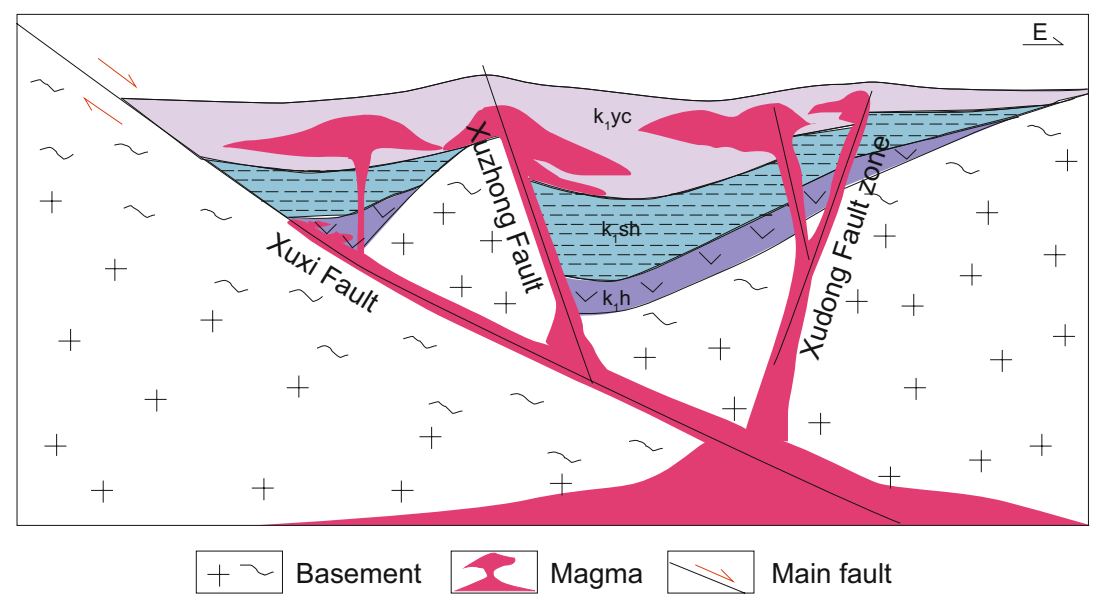

Fig. 4 The model graph of volcanic eruption of $\mathrm{K}_{1} \mathrm{yc}$ 
in the upper formation with a flower structure. On both sides of the Xuzhong Fault in the southern depression, the Shahezi Formation was deformed and displaced (Zhang et al, 2010). It is easy to identify and track the fault in seismic section. However, in the northern depression, the Xuzhong Fault went through the Xingcheng Uplift, and the Shahezi Formation was absent on both sides of the fault, which led to the direct contact of volcanic rocks of $\mathrm{J}_{3} \mathrm{hs}$ and $\mathrm{K}_{1} \mathrm{yc}$. In the fault zone and nearby areas volcanic channel facies developed. In seismic profiles, the volcanic rocks along the fault zone have similar reflection characteristics with the surrounding volcanics, and the structural differences are not obvious, so it is difficult to identify whether or not the fault went through the volcanic rocks from the interpretation of seismic profiles.
Therefore, although the Xuzhong Fault is a large-scale strikeslip fault, it has not been recognized until recently. The reasons are not only the poor quality of previous seismic data, but also the indistinct trace of the Xuzhong Fault which has been affected by the transformation of volcanic activities. Moreover, some other faults (such as the Xudong Fault zone) have the similar transformation effects of volcanic activities. The seismic section in the central Xujiaweizi Fault Depression shows that the channel of magma upwelling cut through the $\mathrm{K}_{1} \mathrm{sh}$, while the strata on both sides of the channel have no obvious distortion. Moreover, the later activities of faults disrupted the strata on the top of $\mathrm{K}_{1} \mathrm{yc}$, which was important evidence to infer that the pre-existing faults were transformed by volcanic activities (Fig. 5(a)).
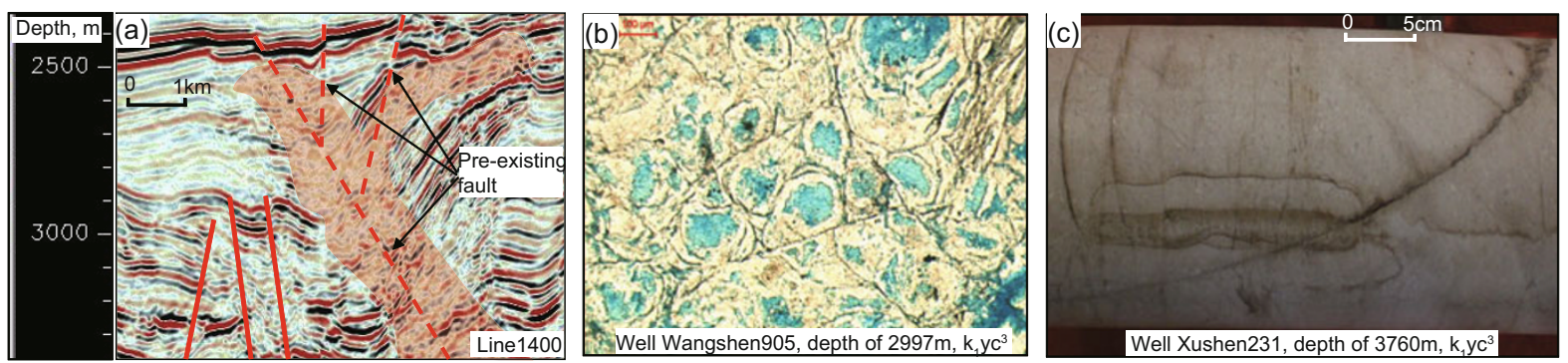

Fig. 5 The relationship diagram of faults (fractures) and volcanic rock (the data was obtained from the Exploration and Development Research Institute of Daqing Oilfield Company Ltd.)

(a) The faults were eroded by magmatic activity, the shaded part is the upwelling magma channel, the red dashed line shows the faults which have been melted and are difficult to identify; (b) Fractures in extrusive facies perlite. The thin-section optical micrograph shows that the perlite was cut by many groups of fractures; (c) The fractures showing in drill core

Volcanic activity is an important tectonism during the formation and evolution of the Xujiaweizi Fault Depression, and has significant impact on the deep strata and structure. The volcanic activities of $\mathrm{K}_{1} \mathrm{yc}$ took place in the critical period of fault-sag transition stage, which was just after a strong extension in the Shahezi rifting period. The deep-seated faults communicated with the basement magma chamber and became the main channels for magma upwelling. The rising magma not only transformed a large number of pre-existing fractures, but also occupied the accommodation space, which led to the formation of a series of compressional structure styles (such as compression anticlines), and the change from an extensional stress field to a compression stress field. The transformation made the deep structure of the Xujiaweizi Fault Depression more complex.

The transformation of volcanic activity on the preexisting faults has a great effect on deep gas exploration, because the faults are the main channels which communicate with the deep source rocks and gas reservoirs. The damaged fault channels make it difficult to understand the natural gas migration and accumulation.

\subsection{Influence of post-fractures on physical properties of volcanic rocks}

The volcanic rocks of $\mathrm{K}_{1} \mathrm{yc}$ were formed in the faultsag transition stage, but the volcanic activities weakened gradually after the period of depression, and the fault activities significantly decreased (Zhao et al, 2008; Zhang et al, 2010; Chen et al, 2012). Although the fault activities were weak during the depression period, they lasted for a long time. The seismic interpretation profile (Fig. 1) reveals that weak fault activities have occurred since the Denglouku period. However, the fault activities had little impact on continuous development of the strata due to their small scale. These small faults were not related to the faults formed in the rifting period, and had no relation with early tectonic movements, but were influenced by the new stress fields of later tectonic movements (Feng, 2008; Zhang et al, 2009; Zhao et al, 2009). Even so, post-fault activities played an important role in improving the physical properties of $\mathrm{K}_{1} \mathrm{yc}$. Many fractures were formed in the volcanic rocks of $\mathrm{K}_{1} \mathrm{yc}^{1}$ and $\mathrm{K}_{1} \mathrm{yc}^{3}$ because of continuous fault activities, and they were found in the thin sections and drill cores of volcanic rocks of erupted and extrusive facies (Figs. 5(b) and 5(c)). A large number of fractures distributed in the volcanic rocks greatly increased the porosity and permeability of volcanic rocks. Taking the volcanic rocks of $\mathrm{K}_{1} \mathrm{yc}$ in the Shengping area as an example, the analysis of drill core showed that the porosity of volcanic rocks where fractures developed could reach $20 \%$, and the maximum horizontal permeability was $52.7 \times 10^{-3} \mu \mathrm{m}^{2}$ and the maximum vertical permeability was $73.1 \times 10^{-3} \mu \mathrm{m}^{2}$. In the volcanic rocks where fractures did not develop, the porosity was generally less than $10 \%$, the horizontal permeability was less than $20 \times 10^{-3} \mu^{2}$, and the vertical permeability was less 
than $30 \times 10^{-3} \mu \mathrm{m}^{2}$. Therefore, fractures have been an important factor which greatly influenced the natural gas storage space of volcanic rocks.

\section{Conclusions}

1) The differences of spatial distribution and lithology between the first and the third member volcanic rocks of the Yingcheng Formation in the Xujiaweizi Fault Depression have been studied. The differences of spatial distribution are controlled by the tectonic evolution, and the differences of lithology reflect different degrees of mixing of the rising magma and the crustal material during the process of volcanic activities. The lithofacies, rock types, and eruption types of the two volcanic members are similar, which shows that the volcanic activities are characterized by the same original magma chamber, multi-stage and intermittent eruptions, and the main faults play an important role in controlling the development of volcanic rocks.

2) Close relationships between the development of volcanic rocks in the Yingcheng Formation and the fault structure are revealed in this paper. The Xuxi Fault is a key fault which reaches the deep magma chamber. After the magma reached the basement of the fault depression, the Xuzhong and Xudong Fault zones controlled the eruption and distribution of the first and the third members of the Yingcheng Formation, respectively. Volcanic activities played an important role in the transformation and erosion of the preexisting faults, made the structural traces of faults unclear, and affected the connectivity of the faults, resulting in the complex deep structure. Meanwhile, the post-fault activities greatly improved the physical properties of the Yingcheng Formation, and a large number of fractures in the volcanic rocks increased the porosity and permeability significantly and provided important spaces and transport systems to form gas reservoirs.

3) The volcanic rocks of the Yingcheng Formation developed in a special period of tectonic evolution in the Xujiaweizi Fault Depression. The initial rifting of the Huoshiling period and the strong extensional movement of Shahezi period caused a series of tensional deep faults in the Xujiaweizi Fault Depression. The faults not only communicated with the deep magma chamber, but also made the rifting center become a weak zone of magma upwelling after stretching and thinning. Therefore, the volcanic activity of the two members of the Yingcheng Formation started to erupt from the central depression to the south or north with fissure type and central-vent type volcanism. The early rifting activities laid the foundation for the development of volcanic rocks of the Yingcheng Formation. The interaction and mutual influence between volcanic rocks and faults occurred during fault-sag transition stage, i.e. the pre-existing faults provided channels for the volcanic eruption, and they were also eroded and transformed by magma. In the depression stage, the fault activities were weak because the stress fields of regional tectonics had weakened. A large number of small fractures developed in almost all layers below the surface, which provided favorable storage space for natural gas, and had little influence on the overburden sealing. Therefore, the volcanic rocks of the Yingcheng Formation are closely related to the faults from the magma upwelling, the volcanic eruption and the diagenetic transformation of rock properties.

\section{Acknowledgements}

This study was supported by the Major State Basic Research Development Program of China (973 Program (No.2012CB214705)) and the National Natural Science Foundation of China (No. 41206035). The authors would like to thank the Exploration and Development Research Institute of Daqing Oilfield Company Ltd. for providing the original data.

\section{References}

Cai Z R, Xia B, Guo F, et al. Controlling mechanism on volcanic rocks of the Yingcheng Formation of the Xujiaweizi rift depression in the northern Songliao Basin. Acta Petrolei Sinica. 2010. 31(6): 941-945 (in Chinese)

Chen J L, Cai X Y, Lin C H, et al. Tectonic characteristics and episodic evolution of the northern fault depression in the Songliao Basin. Acta Petrolei Sinica. 1999. 20(4): 14-18 (in Chinese)

Chen J W, Wang D F, Zhang X D, et al. Analysis of volcanic facies and apparatus of the Yingcheng Formation in the Xujaweizi faulting depression, Songliao Basin, northeast China. Earth Science Frontiers. 2000. 7(4): 371-379 (in Chinese)

Chen X H, He W Y and Feng Z H. Controlling effect of major faults on the gas reservoirs in the Xujiaweizi fault depression, Songliao Basin. Natural Gas Industry. 2012. 32(3): 53-56 (in Chinese)

Chi Y L, Yun J B, Meng Q A, et al. Deep Structure, Basin Dynamics and Hydrocarbon Accumulation in the Songliao Basin. Beijing: Petroleum Industry Press. 2002. 113-221 (in Chinese)

Feng Z Q. Exploration potential of the large Qingshen gas field in the Songliao Basin. Natural Gas Industry. 2006. 26(6): 1-5 (in Chinese)

Feng Z Q. Volcanic rocks as prolific gas reservoirs: A case study from the Qingshen gas field in the Songliao Basin, NE China. Marine and Petroleum Geology. 2008. 25: 416-432 (in Chinese)

He D, Li J H, Liu S J, et al. Discovery of a giant caldera in the Yingcheng Formation in the Xujiaweizi fault depression, northern Songliao Basin. Geology in China. 2008. 35(3): 463-471 (in Chinese)

Hou Q J, Feng Z Q, Lin T F, et al. New development of oil and gas exploration in the Daqing exploration area. Petroleum Geology \& Oilfield Development in Daqing. 2004. 23(5): 4-9 (in Chinese)

Huang W, Shao H M, Zhao H L, et al. Characteristics of the Yingcheng Formation's volcanic reservoir in the Xushen Gas Field in the northern Songliao Basin. Acta Petrolei Sinica. 2006. 27(Supplement): 47-51 (in Chinese)

Jiang C J, Chen S M, Chu L L, et al. A new understanding about the volcanic distribution characteristics and eruption mechanism of the Yingcheng Formation in the Xujiaweizi fault depression. Acta Petrologica Sinica. 2010. 26(1): 63-72 (in Chinese)

Jin X H, Lin R Z, Zou H Y, et al. Volcanic activities and evolution of source rocks in the Xujiaweizi fault depression, Songliao Basin. Oil \& Gas Geology. 2005. 26(3): 349-355 (in Chinese)

Liu D L, Chen F J and Yang F P. Mesozoic volcanic rocks and plate tectonic environments in northeastern China. Journal of Daqing Petroleum Institute. 1994. 18(2): 1-8 (in Chinese)

Liu W Z, Wang P J, Men G T, et al. Characteristics of deep volcanic reservoirs in the northern Songliao Basin. Oil \& Gas Geology. 2003. 24(1): 28-31 (in Chinese)

Meng Q A, Yang Y B and Jin M Y. Controlling role of faults to giant Qingshen Gas Field in the Songliao Basin. Acta Petrolei Sinica. 
2006. 27(Supplement): 14-17 (in Chinese)

Ren Y G, Zhu D F, Wan C B, et al. Geological characteristics of deep layers in the northern part of the Songliao Basin and orientation for natural gas exploration. China Petroleum Exploration. 2004. 9(4): 12-19 (in Chinese)

Tang H F, Pang Y M, Bian W H, et al. Quantitative analysis on reservoirs in volcanic edifice of Early Cretaceous Yingcheng Formation in Songliao Basin. Acta Petrolei Sinica. 2008. 29(6): 842-847 (in Chinese)

Tang J R, Liu J P, Xie C L, et al. Volcanite character and reservoirformed rule for Xujiaweizi fault depression. Oil Geophysical Prospecting. 2001. 36(3): 345-351 (in Chinese)

Wang L, Jin J Q and Zhang Y. Division of volcanic eruption periods of the first and third members of the Yingcheng Formation in the Xujiaweizi fault depression in Songliao Basin. China Petroleum Exploration. 2009. 14(2): 6-13 (in Chinese)

Wang P J, Pang Y M, Tang H F, et al. The characteristics of the paleovolcanic edifice of Yingcheng Formation, Cretaceous, Songliao Basin. Journal of Jilin University (Earth Science Edition). 2007. 37(6): 1061-1073 (in Chinese)

Yin J Y, Liu H F and Chi H J. Evolution and gas-accumulation of the Xujiaweizi depression in the Songliao Basin. Acta Petrolei Sinica. 2002. 23(2): 26-29 (in Chinese)

Zhang E H, Jiang C J, Zhang Y G, et al. Study on the formation and evolution of deep structure of Xujiaweizi fault depression. Acta Petrologica Sinica. 2010. 26(1): 149-157 (in Chinese)

Zhang G L, Lan Z X and Liu P. Fracturing control method for deep volcanic rock gas reservoirs in Daqing exploration area. Petroleum Exploration and Development. 2009. 36(4): 529-534 (in Chinese)

Zhang Y G, Chen S M, Zhang E H, et al. The new progress of Xujiaweizi fault depression characteristics of structural geology research. Acta Petrologica Sinica. 2010. 26(1): 42-48 (in Chinese)

Zhao W Y, Liu W L, Men G T, et al. Prediction method for distribution area and thickness of hydrocarbon source rocks-taking the Xujiaweizi Depression in the Songliao Basin as an example. Acta Petrolei Sinica. 2007. 28(5): 67-71 (in Chinese)

Zhao W Z, Zou C N, Feng Z Q, et al. Geological features and evaluation techniques of deep-seated volcanics gas reservoirs, Songliao Basin. Petroleum Exploration and Development. 2008. 35(2): 129-142 (in Chinese)

Zhao W Z, Zou C N, Li J Z, et al. Comparative study on volcanic hydrocarbon accumulations in western and eastern China and its significance. Petroleum Exploration and Development. 2009. 36(1): 1-11 (in Chinese)

Zou C N, Zhu R K, Zhao W Z, et al. Geologic characteristics of volcanic hydrocarbon reservoirs and exploration directions in China. Acta Geologica Sinica. 2010. 84(1): 194-205

(Edited by Hao Jie) 